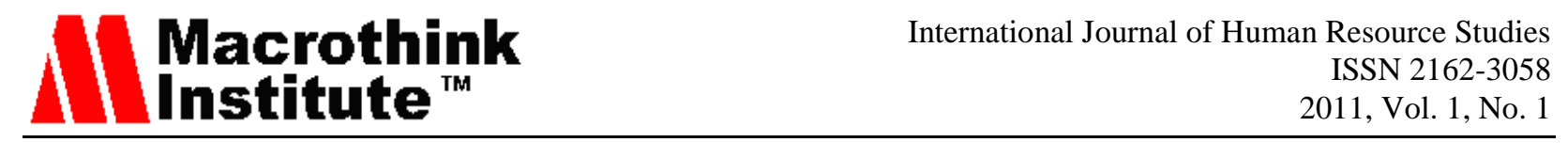

\section{Compensation Management: A strategic conduit towards achieving employee retention and Job Satisfaction in Banking Sector of Pakistan}

\author{
Rabia Inam Khan (Corresponding Author) \\ Research Associate, Human Resource Management Academic Research Society \\ Pakistan \\ E.mail: rabia.khan138@live.com \\ Hassan Danial Aslam \\ Lecturer, Faculty of Management Sciences, The Islamia University of Bahawalpur \\ Pakistan \\ E.mail: Hassan.danial@iub.edu.pk \\ Irfan Lodhi \\ Training Advisor, Human Resource Management Academic Research Society \\ Pakistan
}

Accepted: August 21, 2011 DOI: 10.5296/ijhrs.v1i1.809

\begin{abstract}
This paper explores some basic facts about one of the very important aspect of HRM that is Compensation Management and how it affects the job satisfaction and employee retention in banking sector of Pakistan. This paper seeks to add some contribution towards the compensation management in the banking sector of Pakistan. Researchers have analyzed the success factors of one of the leading bank of Pakistan as a case study in current research in order to explore the leading satisfactory factors, issues and challenges regarding compensation policy of the case study bank. A sample of 450 employees of case study bank has been selected for current research using questionnaire and in depth interviews as leading technique of data collection. Research
\end{abstract}


reveals the changing trend of employees from financial rewards to non financial rewards as well. Along with various success factors by which bank retains its employees, results have shown that work overload, lack of practical approach towards training and seniority oriented incentive plans are some of the major issues which need immediate attention by the administration.

Keywords: Compensation, incentives and benefits, bankers, motivation, satisfaction.

\section{Introduction}

Human resources are the most precious assets of any organizations. They are the corner stone of any working place. They carry out everyday operations including the customer dealing, managing the cash flows, running the machines, decision making, counseling of their subordinates, and including many other vital functions of the organization. People make machines and people run machines. Henry Ford, an American Industrialist pointed out the importance of Human resources by saying: "Take my business, burn up my building, but give me my people and I will build the business right back again”. Undoubtedly, these are the employees of the organization who can take an organization towards prosperity with their hard work and determination and they can also lead an organization towards the downfall if their needs are not being identified and satisfied. Literature has identified various human resource management practices which are considered to be the best practices for retaining and motivating human capital in an organization. One of the early and foremost practices is compensation management which deals with compensating the employees of any organization according to the duties they perform and responsibilities they cope up with.

Human Resources are the key drivers of the prosperity and success of any organization. Unless and until the organization does not offers salary, rewards and due benefits according to its employees needs and wants, it would not be able to conquer the highest level of efficiency and competence of the recruits.

Employee compensation includes all forms of pays given to the employees arising from their employment (Dessler, 2008). Compensation management is one of the strapping feature that organizations use to attract and retain its most valuable and worthy assets. Compensation includes financial as well as non-financial rewards. Today's employees not only require money to fulfill their basic needs but they also necessitate various non-financial rewards and benefits, often known as the Fringe Benefits. These fringe benefits include bonus, retirement benefits, gratuity, educational and medical facilities etc.

The compensation management is considered to be a complex process which requires accuracy and precision and if not carried out properly may lead to organizational concerns. An ideal compensation policy encourages the employees to work harder and with more determination. It also helps the organizations to set the standards that are job related, realistic and measurable. Compensation policies should have a sound integration with other practices of HRM. One of the indispensable functions of compensation policy of any company is to provide growth opportunities to its employees and to create a vigorous competition among the employees in order to have an urge to work more efficiently and proficiently. 
The strength of any financial service providing company also depends on the contentment and inspiration of its employees. Banks are the biggest financial service providers of any nation. The banking sector of the Pakistan dominates the financial services and their prominence has become more visible in last ten years. Various banks in Pakistan have dramatically progressed in their capacity, size, financial outcome and service reputation. Consequently, banking sector of Pakistan has offered employment in various departments with reasonable pay packages and working environment where employees perform with their zeal and zest.

One prominent name in banking sector of Pakistan is of Habib Bank Limited (HBL). HBL has the largest commercial banking network, providing the growth and escalation opportunities to its employees. The bank has a network of more than 1450 branches in Pakistan and operates in more than 55 countries. Its head office is situated in Karachi, Pakistan. With the increasing competition, the employees of HBL strive hard to provide high quality services to its customers. HBL had got the Pakistan best bank award in 2008 which motivates the researchers to conduct in depth case study analysis of compensation system of the said bank. As HBL is considered to be one of the leading banks in Pakistan which is creating its employer brand image in Pakistani economy, researchers have investigated the current compensation management system along with its issues and challenges in present study. The objectives of research is

- To analyze different Compensation Management systems being implemented in case study bank.

- To explore the current challenges and issues regarding compensation system of HBL.

\section{Literature Review}

One of the most integral and utmost part of the management of any organization is the Compensation Management. It is a systematic and periodic approach through which employees are being rewarded for their efforts which they inset at their workplaces. Compensation is comprised of wages, incentives, rewards and other benefits given to the workers. The employees of $21^{\text {st }}$ century work not only for the monetary rewards but also for something "extra" and in Human Resource Management this is referred to as "Benefits".

Rewards are of different types depending on their nature. Rewards have been distinguished in the following types:

- Intrinsic versus Extrinsic Rewards

- Financial versus Non-financial Rewards

- Performance-based versus Membership-based Rewards

Intrinsic rewards are those that are self-initiated rewards. These rewards are based on the selfcontentment arising from the job itself. Intrinsic rewards are often known as intangible rewards, for example being part of a group, a feeling arising from accomplishment of goals and pride and satisfaction arising from one's own work. Whereas extrinsic rewards are the benefits provided by the managers also known as tangible rewards such as salary increment, bonus, sales commission etc. These rewards include monetary rewards, promotions of employees and other different kinds 
of benefits. Financial rewards are those which are given to the employees in the form of money and help to improve the employee's financial position. Non-financial rewards comprise of inexpensive rewards to enhance an employee's morale. Organizations also offer rewards to its employees on the basis of their membership or high performance (DeCenzo and Robbins, 2006). Compensation management is used to motivate and retain employees and ultimately it aims at improving the overall effectiveness of an organization. An organization develops its compensation structures in accordance with its goals, objectives and strategies. Compensation management is advantageous to both employees and employers. It is beneficial for the employer in the sense that it lowers the absenteeism rate. If any employee is happy with his work and he is satisfied with the current salary and benefits he is getting then why would he make a day off from the job? Secondly it helps to motivate the employee to work harder because employees know that after achieving a certain level of goals/target; they would be rewarded or given an increment. Thirdly, it helps to make the employees feel satisfied with their jobs. If the employees are happy with the duties and responsibilities they perform and with the pay and rewards they get in exchange, they would never think of leaving that job and would love to stay with that organization.

Compensation is also advantageous to the employee in a way that it injects self-confidence. Offering different schemes of rewards etc is a way of acknowledging the efforts of employees which helps the employee to ponder on the point that he/she as well as his/her work is being valued by the organization. It also works as stress reliever. When an organization is offering different sorts of insurances to the employee, it will relieve many of his fears.

Low satisfaction from the job and increased absenteeism rate are the consequences arising from the insufficient and inadequate benefits (DeCenzo and Robbins, 2006). Among the 4 M's i.e. Men, Money, Machine and Material, men are the most important. Employees working in any organization are the building blocks of that organization. To keep them happy, satisfied and to retain them in the organization, money given to them in the form of wages should essentially be adequate. An effective management is that which makes a comparison of its compensation plans with the other jobs in the industry or with the established benchmark.

Rizwan (2010) explored that the modern organizations try to integrate employee commitment and the performance level of any organization. To keep the employee's self-esteem and sense of worth elevated, rewards are the most contingent factors that are being used by the management of the organization. The performance evaluation and rewards are the two factors which are considered to be the cornerstone for the performance evaluation programs. So rewards are an essential part of compensation management as well as of performance evaluation program.

Ali \& Ahmed (2009) supported the idea that every employee serving in any organization expects that his organization will provide him healthy working environment, a fair wage to fulfill his needs and will treat him equally without any biases. Employees can even demand more safety and security, power and authority and the duties and responsibilities which they perform in their work premises. Furthermore, they stressed that there is a direct link between organizational performance and employee performance and if employees performance is enhanced, organizational performance will enhance automatically. If organizations want to understand 
these expectations, there should be an understanding of employee motivation (Beer et al., 1984, cited in Ali \& Ahmed, 2009). According to Rasheed et al (2010) along with sound mentoring and coaching mechanisms for employee learning support, motivation of an employee is highly increased by tangible and intangible rewards given to him against his high performance. In this regard, human resource managers always put their heads together for developing and improving comprehensive compensation plan for employees.

Hayat et al. (2010) emphasized that Pays and Benefits are the most important factor that influence the job satisfaction of an employee. The other factors influencing a person's job satisfaction include a fair system of promotions within the company, high quality working conditions, good leadership and positive relationships among the colleagues. An old rule of thumb is that satisfied worker are happy with their job and happy workers are the source of high profits for an organization. Lawler (1971) explored the same point by elaborating that workers with elevated job satisfaction are more determined and prolific, more concerned about the high quality of work and have lower chances of job turnover. The role of compensation management is inevitable in achieving this job satisfaction process.

Similarly, rewards and recognition programs are equally supportive in boosting the morale of employees and keeping the spirits high among the employees of any organization. The basic role of rewards and recognition in any organization is to define the system to pay the employees and to communicate that system to the employees so that they can create a link between their rewards and performance which would enhance an employee's job satisfaction (Flynn 1998, cited in Rizwan 2010).

Kluvers and Tippet (2009) found in their study that intrinsic rewards given to the employees including opportunity for growth, opportunity for achievement, advancements, and challenging tasks and duties in any Not for Profit organization help to increase the motivation level of employees, and such motivated employees are the sign of prosperity for any organization. Arnolds et al. (2007) explored in their study that the utmost reward for the blue collar or labor workers is paid holidays whereas for the frontline employees working in an organization the most valued rewards are the retirement plan. The most important rewards that help to motivate blue collar and frontline employees are fringe benefits including bonus, retirement benefits, gratuity, housing loans, paid holidays, educational and medical facilities etc. So rewards are a source of job contentment and a source of motivation for all levels of employees.

Warsi et al. (2009) have found in their research that as Pakistan is developing day by day, Its work environment is also becoming competitive. In this competitive market, employers demand highly committed employees. Employee's commitment depends upon their satisfaction with their pay packages, jobs and relationships with other employees.

Khan et al. (2011) revealed that the corporate organizations including the banks which attain customers and employees loyalty have successfully conquered high profits, better pays, and rewards structure and have retained their most talented and determined employees. This increased determination and performance of the employees helped to deliver best customer. They found in their research conducted in the twin cities of Pakistan (Islamabad and Rawalpindi) that 
in public and private banks of Pakistan high quality services and increased organizational growth through human resources can be achieved through the factors such as employee compensation and rewards, providing them with training programs, work clarity and clear job description. All these factors have a strong positive influence on achieving service quality. Similarly, Mohanty (2009) supported the same idea while emphasizing that open communication among the employees, reward programs for employees, performance based bonuses and incentives, career development programs and gifts presented to employees on several occasions are the practices that a company can adopt to retain its employees.

\section{Research Methodology}

The research is supported by survey strategy which was conducted to identify the issues of compensation management in banking sector of Pakistan. Detail case study has been constructed of well reputed bank of Pakistan (Habib Bank Limited). Stratified random sampling has been implemented by choosing 100 branches of case study bank. In-depth interviews and questionnaires were used as key sources of collecting the primary data. The sampling method used in this research was Stratified sampling. Two strata were selected as managers and employees in order to attain the perspectives of both sides. The sample size determined by the researchers was 450 with 1.29 margins of error and $99 \%$ confidence level, belonging to two strata explained above. In order to increase reliability of current research, in depth interviews have also been conducted from 200 employees and all branch managers of the sample banks.

\section{Findings and Discussion}

Research results have shown that employees in case study bank (Habib Bank Limited) are contented by the compensatory measures by the bank management. However, certain issues have been unearthed in current study which need immediate attention by competent authorities.

Majority of the respondents have a firm belief that there is a positive and direct relation among rewards and motivation level of an employee. $60 \%$ of the bankers strongly agreed, $24 \%$ employees agreed, $12 \%$ disagreed while just $4 \%$ strongly disagreed to the statement that "there is a direct relation among rewards and motivation level of an employee." This shows that employees of HBL observe clear link between rewards for their work and increased motivation along with career progression.

More than $73 \%$ of the employees agreed that HBL offers fringe benefits including gratuity, pension payment, and medical benefits. There was a high proportion of employees agreeing on the statement that "my organization provides me insurance benefits". 56\% of the respondents strongly agreed while $40 \%$ agreed that HBL is offering them insurance benefits. Interview analysis show that employees have declared their fringe benefits and insurance policy as major components of their compensation plan and have acknowledged one of the major cause of job satisfaction in case study bank. Rewards also included giving opportunities to the employees in order to grow and learn through training and development programs provided by the organization. When respondents were asked about training/learning opportunities provided by bank, results have shown that $60 \%$ of them agreed (with $12 \%$ strongly agreed) that training 
programs by bank are effectual for their career progression and work improvement. However, some of the respondents have shown their apprehension that practical results of training programs are not achieved. They stressed that post training implications are not practicable. Training program get worthless when environment of workplace (include colleague interaction, manager's behavior, facilities, infrastructure, and extreme workload) do not permit to implement the learned concepts and continue with traditional ways of banking system.

Almost half of the respondents have shown their reservation on salary package they are getting against their extreme workload. When asked about their satisfaction with the current salary, more than $56 \%$ of the employees think that there salary is not sufficient. Results show that $44 \%$ of the respondents disagreed, and $12 \%$ strongly disagreed with the statement that their current salary is satisfactory. During in depth interviews respondents expressed that major factor behind these reservations is the overburdened workload. According to the bank employees they are given increased assignments which sometimes are out of their job description. This workload get more augmented in the fiscal year closing days when they have to sit more than ten hours for completing the assignments.

Similarly response on the statement that "my organization has a bonus or incentive plan" was like this: $16 \%$ strongly agreed, 24\% agreed, 32\% disagreed and 24\% strongly disagreed. Although, during interview session, respondents agreed that they avail special benefits other than their salaries such as decreased mark up loan, house allowance and special increments, still most of the respondents have shown their concerns on incentive plan which is not comprehensive and performance oriented. Employees expressed that incentives are given on seniority basis which are not always performance oriented.

On the other side management perspective in interview analysis is expressed by managers that the ability to pay is an imperative factor affecting the compensation policies of HBL. If the management is earning more profit, its paying capacity will automatically elevate. If a firm earns more profit, it will increase the salaries of its employees to let them know that these increased profits are due to their hard-work and efficiency. Management of HBL also shares some proportion of its profit with its employees, which is called Profit-sharing. $46 \%$ respondents agreed that profit sharing scheme offered by bank is highly effective as they get for what they do.

Sometimes while structuring the compensation plans of the bank, factors like seniority and experience level of employees is also considered. Those bankers who are serving the bank and the customers for a long period of time are paid higher than new recruits. Experienced employees have a better know-how about all the matters and they are valued because of their decision making analysis and past experiences. While exploring the factors affecting compensation policies of HBL, one of the major factors affecting proud to be its grade structure. According to bank management organizational grade structure cannot be ignored because it is the basis for deciding which job following under specific job grade should get how much pay.

Managers also told some factors like prevailing wage rates and unpredictability of the events affecting the compensation of HBL. While structuring the pays of employees, existing salaries in the same industry are being considered and salaries are set in accordance with those rates. 
Sometime unpredictable events such as inflation in a country also have a considerable affect on the compensation policies. With the consistent rise in prices of the commodities, management decides to increase the salaries as well so that employees can meet their needs. In addition to that, banking is all about making good relations with the customers and attracting them for banking service. If any banker has good relations with his customers and if customer is bringing large deposit amount for the bank then management often rewards the employee for bringing deposit to the bank and creating good relations with the customers which ultimately result in increasing motivation for organizational and self development of employees.

\section{Suggestions and Recommendations}

Following are the recommendations based on the above results and discussion:

1. Research has shown that most of the new employees were satisfied with their current salary but the experienced employees were not paid according to their duties, so their pay structure needs immense attention. If employees are unable to meet their expenses then it would be very difficult for them to work effectively and efficiently. Employee's satisfaction is the sign of good management and happy environment in any organization.

2. HBL needs to focus a lot on the well being of its most precious assets that is Human resources. The management needs to focus on its human capital which is the primary source of achieving competitive advantage. Healthy balance between employee's work life and life outside the work need imperative importance.

3. A bonus system may be injected in bank to reward efficient and hard working employees so that they can be retained in HBL. Although, sound reward system is also being introduced in bank, yet seniority oriented bonuses should be revised in order to make them performance oriented so that employees could feel transparency in compensatory plans.

4. Moreover, culture of praise and verbal appreciation should be encouraged in bank branches from the manager and senior officers. Since it helps to motivate the employees and keeps them determined towards their work.

As one of the Customer Relationship Officer elaborated that:

"A single word of appreciation from our manager is more than a monetary reward for us”.

\section{Conclusion}

This paper has presented a snapshot about the present and concerning issues of compensation management in Habib Bank Limited along with success factors of the said bank which have retained its employees with increase job satisfaction. The current study has concluded that the compensation management has a direct and intense relation with the job satisfaction as well as job motivation. Results also revealed the changing trend of compensation plans in banking sector of Pakistan. It shows that employees and employers are getting inclined towards financial as well as non financial rewards where appreciation, high performer certificate, delegated authority and many other mechanisms could work well keeping the salary constant. Elaborated issues and 
employee concerns about the system in this research could be beneficial for both future researchers and policy makers of banking sector of Pakistan.

\section{References}

- CA Arnolds and DJL Venter (2007), The strategic Importance of Motivational Rewards for Lower-Level Employee $s$ in the manufacturing and retailing industries. SA Journal of Industrial Psychology, 33 (3), Page 15-23.

- David A. DeCenzo and Stephen P. Robbins (2006) Fundamentals of Human Resource Management, Nice Printing Press Daily, America.

- Flynn, G. (1998). Is your recognition program understood? Workforce,77 (7), page 3035.

- Gary Dessler (2008), Human Resource Management, Prenctice Hall, America.

- Lawler, E. E. 1971, Pay and Organizational Effectiveness: McGraw-Hill, New York.

- Masood Hayat, Gulfam Khan Khalid, Arooj Malik( 2010), Job Satisfaction Among National Highway Authority Employees. International Review of Business Research Papers Vol.6, No.1, Page 319-330.

- Muhammad Asif Khan, Kashif-Ur-Rehman, Ijaz-Ur-Rehman, Nadeem Safwan and Ashfaq Ahmad (2011), Modeling link between internal service quality in Human Resources management and employees retention: A Case of Pakistani privatized and public sector banks. African Journal of Business Management Vol.5 (3), page. 949-959.

- Reena Ali and M.Shakil Ahmed (2009), The Impact of Reward and Recognition Programs on Employee's Motivation and Satisfaction: An Empirical Study. International Review of Business Research Papers. Vol. 5 No. 4 Page 270-279.

- Rizwan Qaiser Danish and Ali Usman (2010), Impact of Reward and Recognition on Job Satisfaction and Motivation: An Empirical Study from Pakistan. International Journal of Business and Management, Vol.5 No.2.

- Rasheed, I, Aslam, H.D and Sarwar, S. (2010). "Motivational Issues for Teachers in Higher Education: A Critical Case of IUB”. Journal of Management Research, Vol. 2 (2),

- Ron Kluvers and John Tippet (2009), The Effect On Motivation of A Change in Rewards. International Review of Business Research Papers, Vol. 5 No. 5, Page 147-159.

- Saif ur Rehman, Muhammad Aslam Khan, Hasan Afzal, Waheed Akhter and Imran Ali (2010) Stress in banker's life: Demands -control model as predictors of employee's activity participation, African Journal of Business Management Vol. 4(9), page 16791690.

- Shelly Mohanty (2009), Retention Depicts The Health Of The Organization. Cambodian Manage. J. 1 (2): page 1-6. 